Tohoku J. exp. Med., 1973, 110, 4l-48

\title{
Pattern of Urinary Acid Mucopolysaccharide Excretion in Five Patients with Genetic Mucopolysaccharidoses
}

\author{
Tadao Orit, Ryoji Minami, Aiko Takase and Tooru Nakao \\ Department of Pediatrics, Sapporo Medical College, Sapporo
}

\begin{abstract}
Orit, T., Mtramr, R., Takase, A. and Nakao, T. Pattern of Urinary Acid Mucopolysaccharide Excretion in Five Patients with Genetic Mucopolysaccharidoses. Tohoku J. exp. Med, 1973, 110 (1), 4I-48— Qualitative and quantitative determinations of urinary acid mucopolysaccharides in five patients with Hurler, Morquio and Scheie syndromes have been studied by several methods including ECTEOLA-cellulose column chromatography, Dowex $1 \times 2$ column chromatography, electrophoresis and enzymatic digestion with testicular hyaluronidase and chondroitinase. 1) Considerable amounts of chondroitin sulfate B, heparitin sulfate and keratosulfate were detected in the urine of two patients with Hurler syndrome compared with that of normal male children. 2) Keratosulfate constituted respectively about one-third $(34.5 \%$ and $29.4 \%)$ of the total acid mucopolysaccharide excreted in two sisters with Morquio syndrome. Each content of all of the acid mucopolysaccharide excreted was greater than that excreted in normal male children. 3) Chondroitin sulfate B and heparitin sulfate comprised $39.0 \%$ and $24.3 \%$ of the total acid mucopolysaccharide excreted in a patient with Scheie syndrome. 4) With the exception of chondroitin sulfates $A$ and $C$ in two brothers with Hurler syndrome, all of the acid mucopolysaccharides found in the urine of normal male children were also identified in the urine of five patients with genetic mucopolysaccharidoses. -___ Hurler syndrome; Morquio syndrome; Scheie syndrome; urinary acid mucopolysaccharides
\end{abstract}

Since both Dorfman and Lorincz (1957) and Meyer et al. (1958) identified large amounts of chondroitin sulfate $B$ and heparitin sulfate in the urine of patients with Hurler-Hunter syndrome, urinary acid mucopolysaccharides have been studied by several workers, and separation of urinary acid mucopolysaccharides has permitted the distinction between the various forms of these syndromes (Terry and Linker 1964; Maroteaux and Lamy 1965; MoKusick et al. 1965; Kaplan et al. 1968; Kaplan 1969). However, the complexity of the composition of urinary acid mucopolysaccharides, that is, heterogeneity of the compound, variation in sulfation, etc. have limited the usefullness of several methods known to be available for connective tissue studies. Quantitative determination of all the acid mucopolysaccharides excreted in urine of patients with these syndromes has therefore not been reported in detail. For these reasons, in the first place, pattern of urinary acid mucopolysaccharide excretion in normal male children was quantitatively analyzed

Received for publication, September $8,1972$.

A part of this study was presented at the 42 th Annual Meeting of the Japanese Biochemical Society, Oct. 1969, Hiroshima and at the symposium of carbohydrate complex in the 44th Annual Meeting of the Japanese Biochemical Society, Oct. 1971, Sendai. 
by authors (Orii et al. 1972) using ECTEOLA-cellulose and sephadex G-25 columns. In this report pattern of urinary acid mucopolysaccharide excretion in five patients with genetic mucopolysaccharidoses has been also quantitatively studied using the similar procedure carried out in the urine of normal male children.

\section{Materials and Methods}

Analytical procedures were the same as previously described by Orii et al. (1972). Urine was collected with thymol as a preservative from five patients: two sibling cases with Hurler syndrome, two sibling cases with Morquio syndrome and one case with Scheie syndrome. Urine specimens were kept frozen until analysis. Each urine was centrifuged and each supernatant was applied to a column $(3.0 \times 66 \mathrm{~cm}$, two cases with Hurler syndrome; $3.0 \times 70 \mathrm{~cm}$, two cases of Morquio syndrome; $4.0 \times 60 \mathrm{~cm}$, one case with Scheie syndrome) of ECTEOLA-cellulose. The columns were washed with $0.9 \% \mathrm{NaCl}$ and acid mucopolysaccharides were eluted with $2.0 \mathrm{M} \mathrm{NaCl}$. Each eluate was concentrated and desalted on sephadex G-25 column $(4.0 \times 120 \mathrm{~cm})$. Crude acid mucopolysaccharides were repeatedly purified by the sodium acetate-ethanol procedure. Subsequently, digestion of each acid mucopolysaccharide with testicular hyaluronidase and chondroitinase $\mathrm{ABC}$, and fractionation of chondroitinase $\mathrm{ABC}$-undigested mucopolysaccharides by column chromatography on Dowex $1 \times 2$ were also carried out as previously described by Orii et al. (1972). However, enzymatic assay of chondroitin sulfates A, B and C was carried out by method II of Saito et al. (1968), that is, three reaction mixtures and a blank mixture were prepared. The reaction mixtures contained, in $150 \mu \mathrm{l}, 30 \mu \mathrm{l}$ of Tris buffer, $20 \mu \mathrm{l}$ of total acid mucopolysaccharide (containing $20 \mu \mathrm{g}$ as uronic acid), and 0.04 unit of chondroitinase $\mathrm{ABC}$ plus 0.02 unit of chondro-6-sulfatase (tube 1), 0.12 unit of chondroitinase AC plus 0.02 unit of chondro-4-sulfatase plus 0.02 unit of chondro-6-sulfatase (tube 2), or 0.04 unit of chondroitinase $\mathrm{ABC}$ plus 0.02 unit of chondro-4-sulfatase plus 0.02 unit of chondro-6-sulfatase (tube 3). The blank mixture differed in that it lacked the enzymes. After incubation at $37^{\circ} \mathrm{C}$ for $30 \mathrm{~min}$, the color development has been attained in the Morgan-Elson reaction (Strominger et al. 1959) and then the absorbance was measured in a Hitachi spectrophotometer (model EPU-2) at $585 \mathrm{~m} \mu$. The concentration of chondroitin sulfates A, B and $\mathrm{C}$ was calculated as described by Saito et al. (1968). A number of analytical determinations was carried out: uronic acid (Dische 1947), hexosamine (Svennerholm 1956), neutral carbohydrate (Smith and Montgomery 1956), total sulfate (Dodgson and Price 1962), Nsulfate (Lagunoff and Warren 1962), creatinine (Bonsnes and Taussky 1945), quantitative estimation of glucosamine/galactosamine ratio (Gardell 1958).

\section{Results}

Table 1 indicates that all of the five patients excrete large amounts of the urinary acid mucopolysaccharides compared with normal male children, and the

TABLE 1. Excretion of urinary acid mucopolysaccharides

\begin{tabular}{ll|r|r|r|r|}
\hline & Type & $\begin{array}{c}\text { Age } \\
(\mathrm{y})\end{array}$ & Sex & $\begin{array}{c}\text { Urinary excretion } \\
\text { Unalyzed }(\mathrm{ml})\end{array}$ & $\begin{array}{c}\text { Uronic acid } \\
\text { (mg/l) }\end{array}$ \\
\hline Case 1 & Hurler syndrome & 9 & M & 490 & 65.6 \\
Case 2 & Hurler syndrome & 4 & M & 790 & 54.4 \\
Case 3 & Morquio syndrome & 12 & F & 2000 & 16.8 \\
Case 4 & Morquio syndrome & 8 & F & 2000 & 23.8 \\
Case 5 & Scheie syndrome & 10 & M & 4400 & 29.3 \\
& Normal children & $3-5$ & M & $9000^{*}$ & 8.0
\end{tabular}

* Pooled urine from 75 healthy children was analyzed. 
molar ratios of uronic acid to hexosamine from two cases with Morquio syndrome are lower than those from the other patients and normal male children. Table 2 also shows that the glucosamine to galactosamine ratios and the proportions of testicular hyaluronidase-resistant materials in total acid mucopolysaccharide from all of the five patients are much higher than those from normal male children. After testicular hyaluronidase digestion, the molar ratios of uronic acid to hexosamine from three cases with Hurler and Scheie syndromes were similar to those from normal male children, however, these molar ratios from two cases with Morquio syndrome showed low values. In the testicular hyaluronidase-resistant acid mucopolysaccharide hexosamine, it was indicated that the proportions of galactosamine from the patients with Hurler and Scheie syndromes were higher than those from normal male children, but in two cases with Morquio syndrome, they showed low values. It was also observed that all of the five patients have very high proportions of the chondroitinase ABC-resistant acid mucopolysaccharides than normal male children. After chondroitinase $\mathrm{ABC}$ digestion, furthermore, molar ratios of uronic acid to hexosamine in the undigested acid mucopolysaccharides of two cases with Morquio syndrome were significantly lower than those of the other patients and normal male children. The relative proportions of the chondroitin sulfates $\mathrm{A}$ and $\mathrm{C}$ from five patients were determined by method II of Saito et al. (1968). Little chondroitin sulfates $\mathrm{A}$ and $\mathrm{C}$ were detected in urine from two cases with Hurler syndrome. However, in two cases with Morquio syndrome and one case with Scheie syndrome, the relative proportions of them were 51.5:48.5, 50.7:49.3 and 90.3:9.7, respectively. Each testicular hyaluronidaseundigested acid mucopolysaccharide from five patients was not digested with chondroitinase AC. The percentages of chondroitin sulfate $\mathrm{B}$ in testicular hyaluronidase-undigested acid mucopolysaccharides from cases 1, 2, 3, 4 and 5 were based on each per cent recovery of the undigested galactosamine containing acid mucopolysaccharide after testicular hyaluronidase digestion. Their values were $66.2 \%, 44.4 \%, 4.0 \%, 10.5 \%$ and $66.2 \%$, respectively. Table 3 indicates that the per cent recoveries of acid mucopolysaccharide-hexosamine in $1.75 \mathrm{M}$ $\mathrm{NaCl}$ fraction from three cases with Hurler and Scheie syndromes were much higher than those obtained from normal male children, whereas those from two

of five patients with genetic mucopolysaccharialoses

\begin{tabular}{c|c|c|c}
\hline \multicolumn{2}{|c|}{ of acid mucopolysaccharides } & $\begin{array}{c}\text { Molar ratios of } \\
\text { uronic acid to } \\
\text { hexosamine }\end{array}$ \\
\hline Uronic acid $(\mathrm{mg})$ & $\begin{array}{c}\text { Hexosamine } \\
(\mathrm{mg} / \mathrm{l})\end{array}$ & $\frac{\text { Hexosamine }(\mathrm{mg})}{\text { Creatinine }(\mathrm{g})}$ & \\
\hline Creatinine $(\mathrm{g})$ & 71.6 & 50.4 & 0.85 \\
46.2 & 47.9 & 55.7 & 1.05 \\
63.3 & 28.5 & 47.7 & 0.54 \\
28.1 & 44.0 & 70.7 & 0.50 \\
38.3 & 33.6 & 36.4 & 0.81 \\
31.7 & 8.6 & 13.8 & 0.86 \\
12.8 & & &
\end{tabular}


TaBle 2. Analytical data on urinary acid mucopolysaccharides of five patients with genetic mucopolysaccharidoses before and after digestion with testicular hyaluronidase, and after digestion with chondroitinase $A B C$

\begin{tabular}{|c|c|c|c|c|c|}
\hline \multirow[b]{2}{*}{ Type } & & \multicolumn{2}{|c|}{ Recovery rates } & \multirow{2}{*}{$\begin{array}{c}\text { Uronic } \\
\text { acid } \\
(\text { molar ratio* })\end{array}$} & \multirow{2}{*}{$\begin{array}{l}\text { Glucosamine: } \\
\text { Galacto- } \\
\text { samine }\end{array}$} \\
\hline & & $\begin{array}{c}\% \text { of } \\
\text { hexosamine }\end{array}$ & $\begin{array}{c}\% \text { of } \\
\text { uronic acid }\end{array}$ & & \\
\hline \multirow{3}{*}{$\begin{array}{l}\text { Case } 1 \text { Hurler } \\
\text { syndrome }\end{array}$} & $\begin{array}{l}\text { Before digestion } \\
\text { with testicular } \\
\text { hyaluronidase }\end{array}$ & 100.0 & 100.0 & 0.85 & $33.7: 66.3$ \\
\hline & $\begin{array}{l}\text { After digestion } \\
\text { with testicular } \\
\text { hyaluronidase }\end{array}$ & 95.0 & 73.4 & 0.56 & $34.7: 65.3$ \\
\hline & $\begin{array}{l}\text { After digestion with } \\
\text { chondroitinase } \mathrm{ABC}\end{array}$ & 31.0 & 54.5 & 1.34 & \\
\hline \multirow{3}{*}{$\begin{array}{l}\text { Case } 2 \text { Hurler } \\
\text { syndrome }\end{array}$} & $\begin{array}{l}\text { Before digestion } \\
\text { with testicular } \\
\text { hyaluronidase }\end{array}$ & 100.0 & 100.0 & 1.05 & $46.0: 54.0$ \\
\hline & $\begin{array}{l}\text { After digestion } \\
\text { with testicular } \\
\text { hyaluronidase }\end{array}$ & 88.7 & 73.5 & 0.68 & $49.3: 50.7$ \\
\hline & $\begin{array}{l}\text { After digestion with } \\
\text { chondroitinase } A B C\end{array}$ & 31.2 & 52.4 & 1.18 & \\
\hline \multirow{3}{*}{$\begin{array}{c}\text { Case } 3 \text { Morquio } \\
\text { syndrome }\end{array}$} & $\begin{array}{l}\text { Before digestion } \\
\text { with testicular } \\
\text { hyaluronidase }\end{array}$ & 100.0 & 100.0 & 0.54 & $46.3: 53.7$ \\
\hline & $\begin{array}{l}\text { After digestion } \\
\text { with testicular } \\
\text { hyaluronidase }\end{array}$ & 47.2 & 24.6 & 0.34 & $94.8: 5.2$ \\
\hline & $\begin{array}{l}\text { After digestion with } \\
\text { chondroitinase ABC }\end{array}$ & 37.0 & 18.2 & 0.27 & \\
\hline \multirow{3}{*}{$\begin{array}{c}\text { Case } 4 \text { Morquio } \\
\text { syndrome }\end{array}$} & $\begin{array}{l}\text { Before digestion } \\
\text { with testicular } \\
\text { hyaluronidase }\end{array}$ & 100.0 & 100.0 & 0.50 & $54.4: 45.6$ \\
\hline & $\begin{array}{l}\text { After digestion } \\
\text { with testicular } \\
\text { hyaluronidase }\end{array}$ & 49.4 & 23.8 & 0.34 & $75.8: 24.2$ \\
\hline & $\begin{array}{l}\text { After digestion with } \\
\text { chondroitinase } \mathrm{ABC}\end{array}$ & 33.0 & 19.2 & 0,18 & \\
\hline \multirow{3}{*}{$\begin{array}{r}\text { Case } 5 \text { Scheie } \\
\text { syndrome }\end{array}$} & $\begin{array}{l}\text { Before digestion } \\
\text { with testicular } \\
\text { hyaluronidase }\end{array}$ & 100.0 & 100.0 & 0.81 & $27.8: 72.2$ \\
\hline & $\begin{array}{l}\text { After digestion } \\
\text { with testicular } \\
\text { hyaluronidase }\end{array}$ & 65.9 & 46.2 & 0.62 & $40.8: 59.2$ \\
\hline & $\begin{array}{l}\text { After digestion with } \\
\text { chondroitinase } \mathrm{ABC}\end{array}$ & 21.2 & 31.6 & 1.03 & \\
\hline \multirow{3}{*}{$\begin{array}{l}\text { Normal male } \\
\text { children }\end{array}$} & $\begin{array}{l}\text { Before digestion } \\
\text { with testicular } \\
\text { hyaluronidase }\end{array}$ & 100.0 & 100.0 & 0.86 & $14.5: 85.5$ \\
\hline & $\begin{array}{l}\text { After digestion } \\
\text { with testicular } \\
\text { hyaluronidase }\end{array}$ & 7.8 & 6.3 & 0.69 & $64.4: 35.6$ \\
\hline & $\begin{array}{l}\text { After digestion with } \\
\text { chondroitinase } \mathrm{ABC}\end{array}$ & 4.9 & 3.6 & 0.82 & \\
\hline
\end{tabular}

* Molar ratios based on hexosamine $=1.00$ 
TABLE 3. Fractionation of urinary chondroitinase $A B C$-undigested acid mucopolysaccharides from five patients with genetic mucopolysaccharidoses on Dowex $1-\times 2$ resin

\begin{tabular}{|c|c|c|c|c|c|c|c|}
\hline Type & Age & $\begin{array}{r}\text { Fraction } \\
(\mathrm{M} \mathrm{NaCl})\end{array}$ & $\begin{array}{c}\text { Recovery } \\
\% \text { of } \\
\text { hexosamine }\end{array}$ & $\begin{array}{l}\text { Uronic } \\
\text { acid } \\
\text { (molar } \\
\text { ratio*) }\end{array}$ & $\begin{array}{l}\text { Total } \\
\text { sulfate } \\
\text { (molar } \\
\text { ratio*) }\end{array}$ & $\begin{array}{c}\text { N-Sulfate } \\
\text { (molar } \\
\text { ratio*) }\end{array}$ & $\begin{array}{c}\text { Neutral } \\
\text { carbohydrate } \\
\text { (molar } \\
\text { ratio*) }\end{array}$ \\
\hline \multirow{4}{*}{$\begin{aligned} & \text { Case } 1 \text { Hurler } \text { syndrome } \\
& \text { synder } \\
& \text { Case } 2 \text { Hurler } \\
& \text { syndrome }\end{aligned}$} & \multirow[b]{2}{*}{9} & 1.75 & 89.9 & 1.43 & 1.57 & 1.06 & 1.35 \\
\hline & & 4.0 & 10.1 & 0.30 & 1.82 & 0.35 & 1.10 \\
\hline & \multirow[b]{2}{*}{4} & 1.75 & 91.7 & 1.32 & 1.37 & 0.84 & 1.36 \\
\hline & & 4.0 & 8.3 & 0.42 & 1.62 & 0.39 & 1.89 \\
\hline \multirow{2}{*}{$\begin{array}{l}\text { Case } 3 \text { Morquio } \\
\text { syndrome }\end{array}$} & \multirow[b]{2}{*}{12} & 1.75 & 22.9 & 0.73 & 1.38 & 0.34 & 2.00 \\
\hline & & 4.0 & 77.1 & Trace & 1.56 & Trace & 1.87 \\
\hline \multirow{2}{*}{$\begin{array}{c}\text { Case } 4 \text { Morquio } \\
\text { syndrome }\end{array}$} & \multirow[b]{2}{*}{8} & 1.75 & 21.5 & 0.64 & 1. 19 & 0.15 & 1.34 \\
\hline & & 4.0 & 78.5 & Trace & 1.72 & Trace & 2.17 \\
\hline \multirow{2}{*}{$\begin{array}{c}\text { Case } 5 \text { Scheie } \\
\text { syndrome }\end{array}$} & \multirow{2}{*}{10} & 1.75 & 90.5 & 1.45 & 0.96 & 0.61 & 1.23 \\
\hline & & 4.0 & 9.5 & 0.27 & 1.14 & 0.15 & 1.50 \\
\hline \multirow{2}{*}{$\begin{array}{c}\text { Normal male } \\
\text { children }\end{array}$} & \multirow[b]{2}{*}{$3-5$} & 1.75 & 68.7 & 0.80 & 1.21 & 0.44 & 1.34 \\
\hline & & 4.0 & 31.3 & Trace & 1.76 & Trace & 1.79 \\
\hline
\end{tabular}

* Molar ratios based on hexosamine $=1.00$

cases with Morquio syndrome were much lower than those of normal male children. Table 4 shows proportions of urinary acid mucopolysaccharides recovered from five patients and normal male children. The percentages of chondroitin sulfates $A$ and $C$ in all of the five patients were much lower than those obtained from normal male children, especially in two cases with Hurler syndrome, only trace amounts of them were detected, whereas the per cent recoveries of chondroitin sulfate $B$ with the exception of case 3, heparitin sulfate and keratosulfate in all of five patients were very high compared to those of normal male children. A significantly high per cent recovery of keratosulfate was obtained from two cases with Morquio syndrome. Table 5 gives the pattern of urinary acid mucopolysaccharide excretion in five patients with genetic mucopolysaccharidoses and normal male children.

\section{Discussion}

With the exception of both chondroitin sulfate $B$ and heparitin sulfate, pattern of the other acid mucopolysaccharide excretion in Hurler syndrome has been scarcely reported. The somewhat raised excretion of chondroitin sulfate was described only by Muir (1969), Berggård and Bearn (1965). In our cases, increased amounts of the various acid mucopolysaccharides with exception of both chondroitin sulfates $\mathrm{A}$ and $\mathrm{C}$ were found. In the urine of patients with Morquio syndrome, the occurrence of keratosulfate, chondroitin salfate B, heparitin sulfate and chondroitin sulfates has been reported by several workers (Zellweger et al. 1961; Pedrini et al. 1962; Kaplan et al. 1968; Sartorelli 1968). Furthermore, Dorfman and Matalon (1972) found an elevated concentration of chondroitin sulfates A and $\mathrm{C}$ in a patient with Morquio syndrome. The data presented indicate that the raised excretion of all of the acid mucopolysaccharides found in normal male 
TABLE 4. Urinary acid mucopolysaccharide composition

\begin{tabular}{l|c|c|c}
\hline Type & Age & $\begin{array}{c}\text { Chondroitin } \\
\text { sulfate A } \\
(\%)\end{array}$ & $\begin{array}{c}\text { Chondroitin } \\
\text { sulfate B } \\
(\%)\end{array}$ \\
\hline Case 1 Hurler syndrome & 9 & Trace & 62.0 \\
Case 2 Hurler syndrome & 4 & Trace & 45.0 \\
Case 3 Morquio syndrome & 12 & 20.2 & 2.5 \\
Case 4 Morquio syndrome & 8 & 17.1 & 12.0 \\
Case 5 Scheie syndrome & 10 & 16.5 & 39.0 \\
Normal male children & $3-5$ & 47.6 & 2.8
\end{tabular}

Values are expressed in $\%$ of total hexosamine excreted.

TABle 5. Pattern of urinary acid mucopolysaccharide

\begin{tabular}{l|c|c|r|}
\hline \multicolumn{1}{c|}{ Type } & Age & $\begin{array}{c}\text { Chondroitin } \\
\text { sulfate A }\end{array}$ & $\begin{array}{r}\text { Chondroitin } \\
\text { sulfate B }\end{array}$ \\
\hline Case 1 Hurler syndrome & 9 & Trace & $44.4(31.3)$ \\
Case 2 Hurler syndrome & 4 & Trace & $21.6(25.1)$ \\
Case 3 Morquio syndrome & 12 & $5.8(9.6)$ & $0.7(1.2)$ \\
Case 4 Morquio syndrome & 8 & $7.5(12.1)$ & $5.3(8.5)$ \\
Case 5 Scheie syndrome & 10 & $5.5(6.0)$ & $13.1(14.2)$ \\
Normal male children & $3-5$ & $4.1(6.6)$ & $0.2(0.4)$
\end{tabular}

Each acid mucopolysaccharide value is expressed as hexosamine $\mathrm{mg} / \mathrm{l}$.

children is found in our cases with Morquio syndrome. In patients with Scheie syndrome, quantitative determination of acid mucopolysaccharides excreted has not been studied in detail. The present study shows that the occurrence of all of the acid mucopolysaccharides found in normal male children is detected in our case with Scheie syndrome, and that with the exception of chondroitin sulfates $\mathrm{A}$ and $\mathrm{C}$, the elevated concentration of the other acid mucopolysaccharides especially of chondroitin sulfate $B$ and heparitin sulfate are found in the urine of this case. It is not known at present why a large amount of different acid mucopolysaccharides is excreted by a patient with genetic mucopolysaccharidosis. To elucidate this problem, the complete structures of both urinary and visceral acid mucopolysaccharide-protein complexes should be accurately analyzed.

\section{Acknowledgment}

This study was supported by a grant from the Ministry of Education.

\section{References}

1) Berggård, I. \& Bearn, A.G. (1965) The Hurler syndrome. A biochemical and clinical study. Amer. J. Med.. 39, 221-229.

2) Bonsnes, R.W. \& Taussky, H.H. (1945) On the colorimetric determination of creatinine by the Jaffe reaction. J. biol. Chem., 158, 581-591. 
from five patients with genetic mucopolysaccharidoses

\begin{tabular}{|c|c|c|c|}
\hline $\begin{array}{c}\text { Chondroitin } \\
\text { sulfate C } \\
(\%)\end{array}$ & $\begin{array}{c}\text { Hyaluronic acid }+ \\
\text { non-sulfated } \\
\text { chondroitin } \\
\text { sulfate }(\%)\end{array}$ & $\begin{array}{l}\text { Heparitin sulfate } \\
\qquad(\%)\end{array}$ & $\begin{array}{c}\text { Keratosulfate } \\
(\%)\end{array}$ \\
\hline Trace & 5.0 & 29.6 & 3.4 \\
\hline Trace & 11.3 & 40.1 & 3.6 \\
\hline 19.0 & 13.6 & 10.2 & 34.5 \\
\hline 16.7 & 16.8 & 8.0 & 29.4 \\
\hline 1.8 & 15.8 & 24.3 & 2.6 \\
\hline 34.2 & 10.4 & 3.4 & 1.6 \\
\hline
\end{tabular}

excretion in five patients with genetic mucopolysaccharidoses

\begin{tabular}{c|c|c|c}
\hline $\begin{array}{c}\text { Chondroitin } \\
\text { sulfate C }\end{array}$ & $\begin{array}{c}\text { Hyaluronic acid }+ \\
\text { non-sulfated } \\
\text { chondroitin } \\
\text { sulfate }\end{array}$ & Heparitin sulfate & Keratosulfate \\
\hline Trace & $3.6(2.5)$ & $21.2(14.9)$ & $2.4(1.7)$ \\
Trace & $5.4(6.3)$ & $19.2(22.3)$ & $1.7(2.0)$ \\
$5.4(9.1)$ & $3.9(6.5)$ & $2.9(4.9)$ & $9.8(16.4)$ \\
$7.4(11.8)$ & $7.4(11.9)$ & $3.5(5.6)$ & $12.9(20.8)$ \\
$0.6(0.7)$ & $5.3(5.8)$ & $8.2(8.8)$ & $0.9(0.9)$ \\
$3.0(4.7)$ & $0.9(1.4)$ & $0.3(0.5)$ & $0.1(0.2)$
\end{tabular}

Hexosamine to creatinine ratios are given in parentheses.

3) Dische, Z. (1947) A new specific color reaction of hexuronic acids. J. biol. Chem., 167, 189-198.

4) Dodgson, K.S. \& Price, R.G. (1962) A note on the determination of the ester sulphate content of sulphated polysaccharides. Biochem. J., 84, 106-110.

5) Dorfman, A. \& Lorincz, A.E. (1957) Occurrence of urinary acid mucopolysaccharides in the Hurler syndrome. Proc. nat. Acad. Sci. USA, 43, 443-446.

6) Dorfman, A. \& Matalon, R. (1972) The mucopolysaccharidoses. In: The Metabolic Basis of Inherited Disease, 3rd ed., edited by J.B. Stanbury, J.B. Wyngaarden \& D.S. Fredrickson, McGraw-Hill Book Company, A Blakiston publication, p. 1250.

7) Gardell, S. (1958) Determination of hexosamines, V. Quantitative chromatographic analysis of mixtures of glucosamine and galactosamine on ion exchange columns. Meth. biochem. Anal., 6, 310-312.

8) Kaplan, D. (1969) Classification of the mucopolysaccharidoses based on the pattern of mucopolysacchariduria. Amer. J. Med., 47, 721-729.

9) Kaplan, D., McKusick, V., Trebach, S. \& Lazarus, R. (1968) Keratosulfate-chondroitin sulfate peptide from normal urine and from urine of patients with Morquio syndrome (mucopolysaccharidosis IV). J. Lab. clin. Med., 71, 48-55.

10) Lagunoff, D. \& Warren, G. (1962) Determination of 2-deoxy-2-sulfoaminohexose content of mucopolysaccharides. Arch. Biochem. Biophys., 99, 396-400.

11) Maroteaux, P. \& Lamy, M. (1965) Hurler's disease, Morquio's disease, and related mucopolysaccharidoses. J. Pediat., 67, 312-323.

12) McKusick, V.A., Kaplan, D., Wise, D., Hanley, W.B., Suddarth, S.B., Sevick, M.E. \& Maumanee, A.E. (1965) The genetic mucopolysaccharidoses. Medicine, 44, 445483.

13) Meyer, K., Grumbach, M.M., Linker, A. \& Hoffman, P. (1958) Excretion of sulfated mucopolysaccharides in gargoylism (Hurler's syndrome). Proc. Soc. exp. Biol. Med. (N.Y.), 97, 275-279. 
14) Muir, H. (1969) The structure and metabolism of mucopolysaccharides (glycosaminoglycans) and the problem of the mucopolysaccharidoses. Amer. J. Med., 47, 673690.

15) Orii, T., Minami, R. \& Nakao, T. (1972) Pattern of urinary acid mucopolysaccharide excretion in normal male children. Tohoku J. exp. Med., 108, 369-375.

16) Pedrini, V., Lennzi, L. \& Zambotti, V. (1962) Morauio isolation and identification of keratosulphate in urine of patients affected by Morquio-Ullrich disease. Proc. Soc. exp. Biol. Med. (N.Y.), 110, 847-849.

17) Saito, H., Yamagata, T. \& Suzuki, S. (1968) Enzymatic methods for the determination of small quantities of isometric chondroitin sulfates. J. biol. Chem., 243, 15361542 .

18) Sartorelli, C. (1968) Urinary acid mucopolysaccharides in Morquio's disease. Lancet, 2, 737-738.

19) Smith, F. \& Montgomery, R. (1956) End group analysis of polysaccharides, II. 4. E. Phenol-sulfuric acid. Meth. biochem. Anal., 3, 182.

20) Strominger, J.L., Park, J.T. \& Thompson, R.E. (1959) Composition of the cell wall of staphylococcus aureus: Its relation to the mechanism of action of penicillin. $J$. biol. Chem., 234, 3263-3268.

21) Svennerholm, L. (1956) The determination of hexosamines with special reference to nervous tissue. Acta soc. med. upsalien., 61, 287-306.

22) Terry, K. \& Linker, A. (1964) Distinction among four forms of Hurler's syndrome. Proc. Soc. exp. Biol. Med., 115, 394-402.

23) Zellweger, H., Ponseti, L.V., Pedrini, V., Stamler, F.S. \& Noorden, G.K. (1961) Morquio-Ullrich's disease, $J$. Pediat, 59, 549-56l. 